\title{
THE CONDITIONS OF PRACTICIMG ASSOCIATION FOOTBALL BY WOMEN
}

\author{
Barbara Zdunek, 1, , B, D Maria Alicja Nowak², A, C, D, E \\ ${ }^{1}$ Akademia Piłkarska Oleśnica \\ ${ }^{2}$ Faculty of Physical Education and Health Promotion, University of Szczecin, Poland

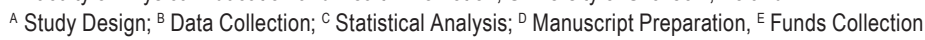 \\ Address for correspondence: \\ University of Szczecin, Faculty of Physical Education and Health Promotion \\ Al. Piastów 40b, building 6, 71-065 Szczecin, Poland \\ E-mail: maria-nowak@wp.pl
}

\begin{abstract}
Ahstract The aim of the work was to learn about the conditions of practicing football by women and to determine positive effects and negative stereotypes accompanying this discipline, the basis being the opinions of female players, as well as student selfgovernment representatives. The study was conducted among 100 Polish female footballers from Exstraliga, 1st League and 2nd League, along with 31 members of student self-governments, representing all physical education universities in Poland. The diagnostic survey method was employed and the techniques of questionnaire, interview and participatory observation were used. For the statistical inference frequency of characteristics, the chi-square test of independence and multiple correspondence analysis were applied. The analyzes confirmed a significant correlation between the recognition of benefits of playing football by women, the perception of the functioning of negative stereotypes and the sporting level of the groups distinguished. The 2 nd and 1 st League players associated practicing football with the possibilities for developing their personality traits, physical fitness and health, and promoting the discipline (in each case $p \leq 0.05$ ). All the footballers emphasized the risk of injury. The Extraliga players most often felt the stereotypical perception of female footballers as non-heterosexual $(p \leq 0.05)$. Attribution of nonheterosexuality to female footballers was confirmed by self-government activists $(p \leq 0.05)$. Women who played football showed a high tolerance toward non-heterosexual people. The Extraliga players were characterized by the highest tolerance $(p \leq 0.05)$. CPEU activists represented stereotypical views on the selection of typically feminine sports. Among ten disciplines suitable for women, they did not list women's football.

There is an urgent need for public education to combat negative stereotypes concerning women practicing traditional male sports disciplines, as well as for tolerance toward people of a different sexual orientation.
\end{abstract}

Key Wordls women's football, stereotypes, sexual orientation

\section{Introduction}

Female football has been an Olympic sport since 1996. Polish women who practice this sports discipline, regularly occur in the Champions League competition. In 2013 the under-17 female Polish national team won the gold medal at the European Championships (http://www.90minut.pl). Nevertheless, matches played by male teams are attended by crowds of fans, sometimes also stadium hooligans (Sahaj, 2012; Brzana, Nowak, Nowak, 2016), while women's games take place with nearly empty stands (Jakubowska, 2009). 
Women involved in sports which are considered typical for men, are attributed with male characteristics, excessive muscularity, loss of femininity, neglecting the roles traditionally attributed to females (Mikołajczyk, 2003; Jakubowska, 2009). Sex is the most common basis for this stereotyping. Categories of femininity and masculinity are closely related, despite different patterns accepted in a given culture or era (Mandal, 2000). Patterns of femininity emphasize delicacy, sensitivity, shyness, protectiveness, thoughtfulness, care about appearance, and even coquetry. Patterns of masculinity underline dominance, rivalry, focus on success, feistiness, arrogance, selfconfidence, physical fitness (Mikołajczyk, 1995), aggression and brutality (Jakubowska, 2013).

Women who play football struggle with many problems and prejudices (Hively, El-Alayli, 2014; Jakubowska, $2012,2015)$. Stereotypes also affect other sports that women try to practice. These disciplines are also referred to in literature as male sports or gender inadequate sports (Mazur, Organista, 2015). Stereotypes act as a preservative agent that maintains the existing state and inhibits changes in many spheres of life (Kofta, Jasińska-Kania, 2001), also in relation to football practiced by women (Andreis, 2012). One argument against women doing sports points to health considerations and difficulties in performing maternal roles. The evolution of social consciousness in recent decades has resulted in many sports disciplines, which so far were practiced only by men, becoming also available to women. Women can, for example, practice martial arts or combat sports and derive specific benefits from it (Boguszewski et al., 2015; Nowak et al., 2009, 2010). According to sports theorists, practicing typically masculine sports by women (combat ports, weightlifting, hammer throw, pole vault, ski jumping, mountain climbing, bodybuilding, team sports games, including football) can cause loss of health in the athletes. The reason for this situation may also be a shortage of specialized literature for optimizing women's training process (Bergier, 2009; Szark-Eckardt, Napierała, Kuska, Żukowska, Żukow, 2013).

One can agree with these opinions if we take into account only the biological roles of women. Numerous examples attest that women overcome these barriers and will continue to overcome them. Performing exercises on uneven bars (static and dynamic elements) requires tremendous coordination abilities and physical condition, not smaller than in the case of the mentioned pole vault. A performance on the bars involves supporting the athlete's body weight mainly on her arms in various positions throughout the duration of a dozen or more elements joined together in a dynamic manner (several seconds). Critical remarks concerning this sport as unsuitable for women, however, are not heard very often, as compared to, for instance, pole vault. One argument against females practicing 'masculine' sports disciplines is some women's 'strong' built. But when one reads a statement by a leading female shot putter, who ascertains that for her sport is a method of self-realization, finding a place where she belongs with her 'big body' among her friends, and getting rid of her complexes, it is not difficult to agree with her choice. The kind of built which predisposes a person to practicing e.g. shot put or hammer throw is naturally taken advantage of by choosing an appropriate sports discipline (Nowak, 2008). At the same time, the observed excessive exploitation of one's own body, including endeavors to reduce or increase its weigh (often with the use of pharmaceuticals), must be met with opposition, especially from pedagogues, physical education and sport theorists (Osiński, 2002) and physicians.

Women who practice team sports, especially footballers, face unpleasant stereotypes, prejudices and suspicions concerning their behavior, aggression, masculine physique, as well as sexual orientation (Andreis, 2012; Butler, 2008). Athletes who do not fit in heteronormativity are stigmatized, labeled (Jakubowska, 2013). Football is considered a 'male game', while women are placed on its margins (Jakubowska, 2015). Despite the obstacles encountered, in the 2014/15 season, 16,183 female football players were officially registered in Poland (Women's 
Football Across the National Associations 2014-2015. UEFA Report). Young girls and women are attracted by physical activity which is linked to sporting rivalry, ability to work together and mutual understanding in fast-changing situations on the field. Football matches are accompanied by positive emotions which encourage them to practice this discipline.

The aim of the work was to learn about the conditions of practicing football by women and to determine positive effects and negative stereotypes accompanying this discipline, the basis being the opinions of female players as well as student self-government activists.

\section{Research material and methods}

The study was conducted among 100 female footballers from different leagues (Exstraliga, 1st League and 2nd League). The respondents were players of leading sports clubs in Poland. The study also included 31 activists (18 women and 13 men) of the student self-governments, who were present at the Congress of the Committee of Physical Education Universities (CPEU). Social characteristics of the female footballers and student self-government activists examined were presented in Table 1.

Table 1. Social characteristics of the respondents

\begin{tabular}{|c|c|c|c|c|c|}
\hline \multirow{3}{*}{ Characteristics } & \multicolumn{3}{|c|}{$\begin{array}{c}\text { Women } \\
\text { who practice football }\end{array}$} & \multicolumn{2}{|c|}{$\begin{array}{c}\text { Student } \\
\text { self-government activists }\end{array}$} \\
\hline & Exstraliga & 1st league & 2nd league & women & men \\
\hline & \multicolumn{5}{|c|}{$\%$} \\
\hline Number of subjects (n) & 62 & 23 & 15 & 18 & 13 \\
\hline \multicolumn{6}{|l|}{ Age: } \\
\hline Under 18 years old & 31.2 & 40.9 & 12.5 & - & - \\
\hline $18-24$ & 47.5 & 27.3 & 81.3 & 83.3 & 92.3 \\
\hline 25 and above & 21.3 & 31.8 & 6.2 & 16.7 & 7.7 \\
\hline \multicolumn{6}{|l|}{ Place of residence: } \\
\hline Countryside & 83.6 & 81.8 & 62.5 & 83.3 & 84.6 \\
\hline City & 16.4 & 18.2 & 37.5 & 16.7 & 15.4 \\
\hline \multicolumn{6}{|l|}{ Education: } \\
\hline Secondary and below & 37.7 & 50.0 & 12.5 & - & - \\
\hline Studying & 34.4 & 27.3 & 62.5 & 77.8 & 76.9 \\
\hline Higher & 27.9 & 22.7 & 25.0 & 22.2 & 23.1 \\
\hline \multicolumn{6}{|l|}{ Career: } \\
\hline Yes & 27.9 & 27.3 & 6.3 & 27.8 & 46.2 \\
\hline No & 72.1 & 72.7 & 93.7 & 72.2 & 53.8 \\
\hline \multicolumn{6}{|l|}{ Marital status: } \\
\hline Spinster & 85.3 & 86.4 & 100.0 & 83.3 & 92.3 \\
\hline Informal relationship & 13.1 & 13.6 & - & - & - \\
\hline Married & 1.6 & - & - & 16.7 & 7.7 \\
\hline
\end{tabular}

Most of the footballers were under 24 years of age. The players lived in cities, did not work professionally, studied. The student self-government activists were a bit older, mostly from cities and still studying. Male selfgovernment members more often worked. Most of the footballers reported being single or in an informal relationship. The CPEU activists were single or married. 
In the collection of the material, the diagnostic survey method was employed, with the use of the techniques of questionnaire, interview and participatory observation. For the statistical inference frequency of characteristics, the chi-square test of independence and multiple correspondence analysis were applied (van Buuren, de Leeuw 1992). These analyses are available in the statistical software package Statistica 12 [StatSoft, inc. 2015 Statistica for Windows]. For the correlations studied, statistical significance at the level of $p \leq 0.05$ was assumed.

\section{Research results}

In order to achieve the objective of the study, it was important to examine the opinions of the respondents regarding the division of sports disciplines into those intended solely for women and those intended solely for men. Most of the female footballers and CPEU activists accepted the division of sports into typically masculine and typically feminine (Table 2). In this group, the players from Exstraliga less often acknowledged the division (about $65 \%$ of the respondents for both classifications). More often it was the players from the lower leagues (1st and 2nd League) ( $p \leq 0.05$ for the $x^{2}$ test). The classifications of typically masculine and typically feminine disciplines produced by female CPEU activists did not differ statistically significantly from those produced by male activists.

Tahle 2. Recognition of the division of sports disciplines into typically masculine and typically feminine by the respondents (independence $x^{2}$ test)

\begin{tabular}{|c|c|c|}
\hline \multirow{3}{*}{ Respondents } & \multicolumn{2}{|c|}{ Classification } \\
\hline & masculine disciplines & feminine disciplines \\
\hline & \multicolumn{2}{|c|}{$\%$} \\
\hline \multicolumn{3}{|l|}{ Female footballers* } \\
\hline Exstraliga & $65.6^{*}$ & $64.0^{*}$ \\
\hline I league & 91.9 & 91.9 \\
\hline II league & 81.5 & 75.0 \\
\hline \multicolumn{3}{|l|}{ CPEU activist } \\
\hline Women & 66.7 & 55.6 \\
\hline Men & 84.6 & 23.1 \\
\hline
\end{tabular}

"Statistical significance at $p \leq 0.05$ was adopted.

The respondents named 10 sports disciplines most suitable for women and for men (Figure 1).

Based on an analysis of the frequency of characteristics, the sports disciplines were positioned hierarchically, ten points being given for the first place, nine for the second, etc. The footballers and the self-government activists similarly ranked disciplines which they regarded as appropriate for women. Synchronized swimming, gymnastics and ballet were the ones most often indicated by the players, as well as the CPEU activists, who also mentioned dancing as a typically feminine discipline. The players put football in the eighth place. The CPEU activists did not consider this discipline to be suitable for women, as well as figure skating. All the respondents indicated combat sports and rugby as the most appropriate for men. In the view of the women who practiced football, next on the list were ski jumping, water sports and motor sports. For the CPEU activists, American football, weightlifting and martial arts were more 'masculine' sports. Football as a sport intended only for men was ranked tenth. 


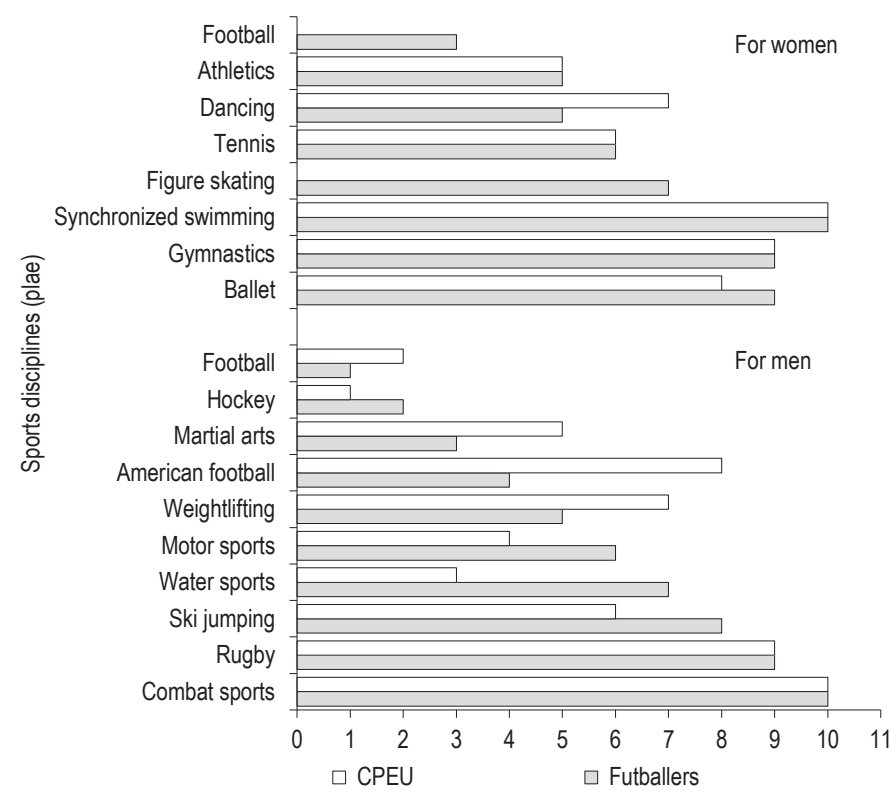

Figure 1. Kinds of sports disciplines intended solely for men and solely for women in the opinion of the respondents (\%)

In the analyses concerning the conditions of practicing football by women, opinions of the CPEU activists were compared with those of the female players (Table 3).-

Table 3. The conditions of practicing football by women in the opinion of female footballers and student activists (independence $x^{2}$ test)

\begin{tabular}{|c|c|c|c|c|c|}
\hline \multirow[t]{3}{*}{ Specification } & \multicolumn{3}{|c|}{$\begin{array}{l}\text { Women who practice football } \\
\qquad(n=100)\end{array}$} & \multicolumn{2}{|c|}{$\begin{array}{c}\text { Student } \\
\text { self-government activists } \\
(n=31)\end{array}$} \\
\hline & Exstraliga & 1st League & 2nd League & women & men \\
\hline & & & $\%$ & & \\
\hline Equality & 17.7 & 22.7 & 12.5 & 33.3 & 38.5 \\
\hline Freedom to choose & 21.0 & 9.1 & - & 27.8 & 23.1 \\
\hline Promotion of the discipline & $24.2^{*}$ & 40.9 & $68.8^{*}$ & 50.0 & 23.1 \\
\hline Physical fitness and health & $25.8^{*}$ & 45.5 & $56.3^{*}$ & $61.1^{*}$ & 23.1 \\
\hline Development of personality & $25.8^{*}$ & 27.3 & $68.8^{*}$ & 77.8 & 53.9 \\
\hline Fighting stereotypes & 29.1 & - & 6.3 & 38.9 & 15.4 \\
\hline Injuries & 85.5 & 81.8 & 87.5 & 38.9 & 53.9 \\
\hline Accusation of different sexual orientations & 65.0 & 45.5 & 50.0 & $61.1^{*}$ & 23.1 \\
\hline
\end{tabular}

"Statistical significance at $p \leq 0.05$ was adopted. 
The respondents stressed that practicing football by women was possible due to equality ( $38 \%$ of the footballers examined). Women's football national and world competitions are held, with separate sport classifications. Equality is connected with the freedom to choose (35\% of the responses) this discipline from a wide range of sports, because it satisfies the need for intensive physical activity, teamwork and experiencing many positive emotions. As far as these factors are concerned, no statistically significant differences were observed. For $35 \%$ of the respondents it was also important to promote football among girls. The 2 nd League players attached more importance to this opportunity ( $p \leq 0.05$ for the $x^{2}$ test). The need for the promotion of football was also recognized by $38.7 \%$ of the CPEU activists, who did not, however, place it among the disciplines which according to them were the most suitable for women (see Figure 1). In the opinion of $35 \%$ of the female footballers and $45.2 \%$ of the CPEU activists, practicing football was beneficial in developing physical fitness and health. These effects were most often appreciated by the 2nd League players ( $p \leq 0.05$ for the $x^{2}$ test) and the female CPEU activists ( $p \leq 0.05$ for the $x^{2}$ test). Development of personality traits through practicing sport was also important. This indirect effect of engaging in competitive sport was noticed by $33 \%$ of the female players, most often from the 2 nd League ( $p \leq 0.05$ for the $x^{2}$ test), and $67.7 \%$ of the female CPEU activists.

For $38 \%$ of the female players, practicing football meant resistance to the stereotype according to which football was a typically masculine sport. The existence of this stereotype and the necessity to fight it was emphasized the most by the Extraliga players, who had been training the longest, and had the greatest sports achievements. In individual utterances, they said that they constantly had to prove their specialized and tactical skills, delight with their psychophysical condition, and impress with their commitment both during practices and matches. A distinctly felt negative effect of practicing football by women was frequent injuries, mentioned by most players regardless of their sporting level (85\%). The risk of injury was assessed as over twice as low (33\%) by the CPEU activists. The women who practiced football encountered various prejudices concerning their possible sexual orientation. They were perceived by the players from all the leagues (57\% of the total), as well as the CPEU activists (45.2\%); more often the female ones ( $p \leq 0.05$ for the $x^{2}$ test).

Detailed data illustrating the issue of female footballers being perceived as non-heterosexual by their closest environment were shown in Table 4.

Table 4. Attitudes of female footballers and CPEU activists toward non-heterosexuality (independence $x^{2}$ test)

\begin{tabular}{lccc}
\hline \multirow{2}{*}{ Respondents } & \multicolumn{3}{c}{ Non-heterosexuality of female footballers } \\
\cline { 2 - 4 } & yes & no & I do not know \\
\cline { 2 - 4 } & & $\%$ & \\
\hline Female footballers & 65.0 & 15.0 & 20.0 \\
Exstraliga & 45.5 & 13.6 & 40.9 \\
1st League & 50.0 & 12.5 & 37.5 \\
2nd League & & & 11.1 \\
CPEU activists & $61.1^{\circ}$ & 27.8 & 53.9 \\
Women & 23.1 & 23.1 & \\
Men & & & \\
\hline
\end{tabular}

Statistical significance at $p \leq 0.05$ was adopted. 
Opinions confirming the functioning of this negative stereotype dominated among $58.2 \%$ of all the players and $45.2 \%$ of the CPEU activists. The female CPEU activists were more often $(61.1 \%)$ aware of its existence ( $p \leq 0.05$ for the $x^{2}$ test).

The respondents female footballers showed various attitudes toward non-heterosexuals (Figure 2).

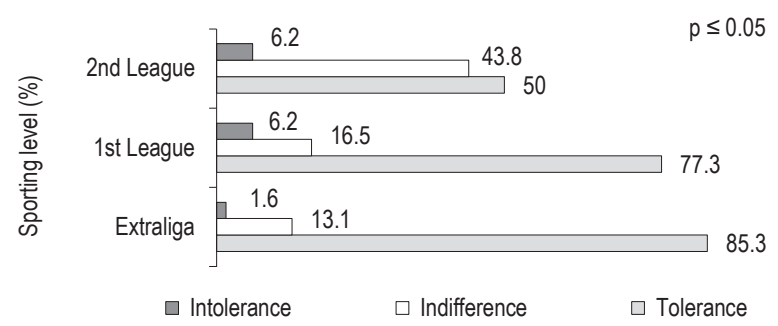

Figure 2. Attitudes of female footballers toward non-heterosexuality (independence $x^{2}$ test)

There was a statistically significant relationship between tolerance toward non-heterosexuals and the subjects' sporting level ( $p \leq 0.05$ for the $x^{2}$ test). The players who were at the highest sporting level (Exstraliga and 1 st League) were characterized by the highest level of tolerance toward non-heterosexual people $(85.3 \%$ and $77.3 \%$ resp.). The 2nd League footballers more often showed indifference (43.8\%). Few players declared intolerance toward people of a different sexual orientation.

The CPEU activists' attitudes toward non-heterosexuals did not differ significantly. The female activists were characterized by a higher level of tolerance toward different sexual orientations $(72.2 \%)$ in comparison with the male ones (38.5), among whom the numbers for the indifferent and the intolerant attitudes were similar ( $30.8 \%$ each).

The diverse circumstances accompanying practicing football by female players from Exstraliga, 1st and 2nd Leagues were presented in Figure 3.

Multiple correspondence analysis based on Burt tables was used. From all characteristics, two dimensions were selected for the analysis (the first and the second), which were represented by co-operating variables. These dimensions explained $37.47 \%$ of the total value of $X^{2}$, including the first dimension: eigenvalue $=0.29$, inertia percentage $=22.53 \%$, and the second dimension: eigenvalue $=0.19$, inertia percentage $=14.94 \%$. For graphical analysis, three groups were isolated: female footballers from Extraliga $(E)$, 1st League and 2nd League. The Exstraliga players (E) pointed to the frequent injuries accompanying the practicing of the sport the most (4a). They saw the existence of stereotypes concerning the discipline they practiced and underlined the need to fight them (5a). The Extraliga players most often felt that female footballers were perceived as non-heterosexual (6a). The players with the highest sporting level $(E)$ to a lesser degree associated practicing football with the opportunity to develop physical fitness and health (2b) or promote the discipline (3b). The last mentioned factors, however, were emphasized by the 1st League players, in whose opinion practicing football created possibilities for developing physical fitness and health (2a) and promoting the discipline (3a). The 1st League players more rarely treated practicing football as a form of fighting stereotypical beliefs (5b) of the closest environment. Even though nearly half of the 1st League players felt that female footballers were perceived as non-heterosexual $(45 \%)$, the rest of them 


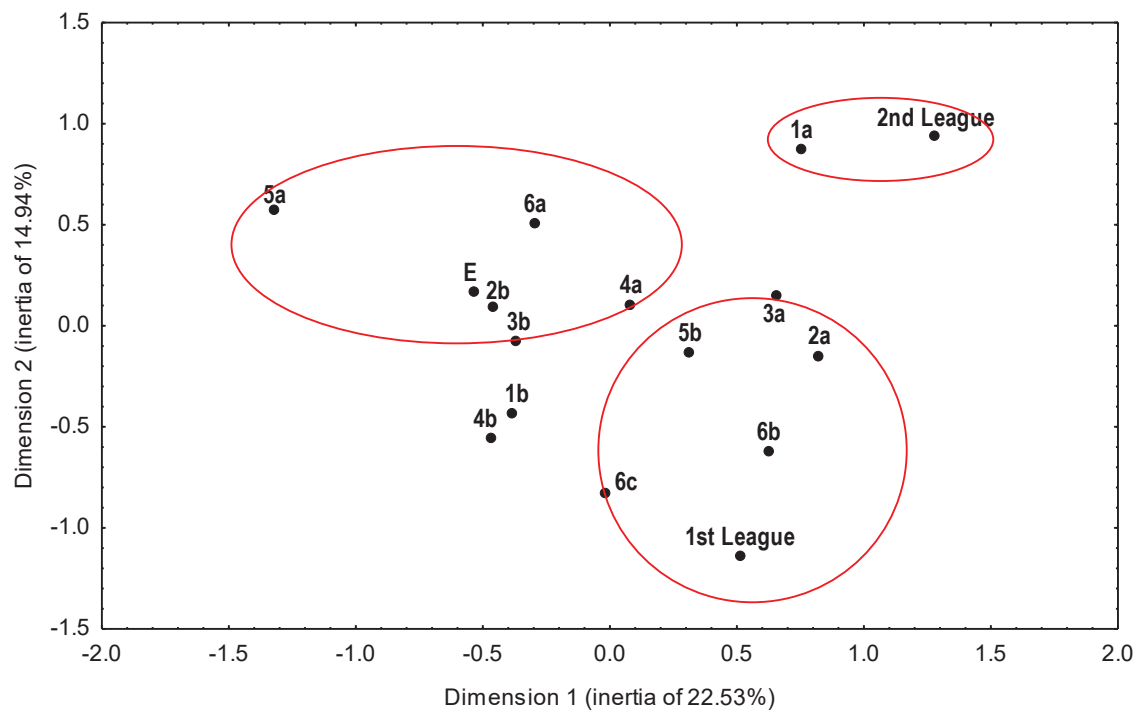

Figure 3. Relationships between the conditions of practicing football by women and their sporting level (multiple correspondence analysis)

were not familiar with this phenomenon (6b, 6c). Practicing football had the greatest influence on the development of personality traits in the opinion of the 2nd League players (1a). The footballers from the highest leagues ( $E$ and $1 s t$ League) to a lesser degree associated practicing football with the opportunity to develop their personality (1b) and the lack of injuries (4b). The analyses confirmed a statistically significant correlation between perceiving benefits of practicing football by women (mainly 2nd and 1st Leagues), pointing to the functioning of negative stereotypes (mainly Exstraliga) and the sporting level of the particular groups.

\section{Discussion}

Women today have full access to education and professional work, although their salaries are still lower compared with those of men with similar education and competencies. Women may also participate in public and political life, but the weight of their choices, which may cause traditional role conflicts, is emphasized (Mikołajczyk, 2003). The role of women in society is closely connected with the situation in sport, where there is no clear and explicit discrimination against women. Evidence of progressive changes might be seen in the inclusion of a growing number of sports available to women in the Olympic Games program. Equal rights for women are also guaranteed by the Constitution of the Republic of Poland (Konstytucja Rzeczypospolitej Polskiej, 1997). It is worth noting that the Statute of the Polish Football Association contains a clause on the prohibition of discrimination. It reads as follows: "§ 2. Any discrimination against a country, an individual or a group of people with regard to the organization or practice of the sport of football for reasons of ethnicity, gender, language, religion, political beliefs or any other reasons is explicitly prohibited under the threat of disciplinary sanctions, including suspension or exclusion from the Association" (Statute of the PFA Art. 7, Neutrality and non-discrimination, https://www.pzpn.pl/public/635/47). At the same time, the membership of girls and women in sports clubs participating in sports competitions organized 
by the Polish sports associations amounted to about $12 \%-14 \%$ in the previous years, while female football players accounted for $0.8-2.8 \%$. The sport was more often practiced by juniors (1.2-5.3\% of all footballers) than senior players (0.5-1.1\%) (Włoch, Skóra, Szankin, Szeptycka, 2013). Own research involving people from different leagues, also indicate a significant number of juniors.

The literature stresses the negative impact of sport on women's health, connected for example with the inadequacy of sporting regulations, techniques and training load, which do not take into account women's physiological capabilities. Part of the explanation for this phenomenon is the situation in sport. The decision-making positions in sports organizations and institutions are occupied mainly by men. This is true in all Western countries, Australia, the USA, and in Poland as well. Increasing women's participation in the governing bodies of sports organizations could have a lot of positive effects and bring about more adequate solutions in the field of women's sport. Such changes are called for by, among others, T. Socha (2002), G. Pfister, (2003/2004). Recent research has shown that gender inequality is manifested in the appointment of offices in Polish sports organizations (such as offices of presidents, vice presidents, chairpersons and vice-chairpersons of committees). Fewer women work in Polish organizations than in international and British ones; there are also fewer women in women's sport committees (if they have been created). More women work in organizations that are traditionally considered feminine (Organista, 2017).

There is no doubt, however, that women's capabilities of holding executive positions have some limitations. These include: individual factors (competencies, motivations, priorities, attitudes acquired in the process of socialization - leadership qualities, the ability to fight for prestige, etc.), time budget, material resources (ability to work, support from the family and partner, the influence of the community, important contacts and connections), genuine or perceived conflicts between the career in sport and other spheres of life (partner, children). Women's opportunities for occupying managerial positions are seriously limited by their family situation. The existing gender inequality in this respect is not a sign of the struggle with men, but an attempt to identify the social and cultural background and get to know the logic of decision-making processes (Gieß-Stüber, 2000).

One of the most important values in modern Western societies is the freedom to individually choose a lifestyle, and shape and recognize different desires and aspirations (Hively, El-Alayli, 2014; Jakubowska, 2009, 2015). Women make these choices and take on various challenges, also in the field of sport. Most female players recognize the division into typically masculine and typically feminine sports disciplines. The Exstraliga players less often accept the division. Acknowledged are those disciplines (synchronized swimming, gymnastics and ballet), which serve the image of a modern women. Even female footballers listed football as low as in the eighth place. This testifies to the strong influence of this stereotype and to female footballers being subject to it, despite their declared endeavors to fight the phenomenon. As far as the CPEU activists' ranking of ten sports disciplines is concerned, they did not mention football as a discipline suitable for women, but they placed it only in the 10th place among sports for men. Problems of women who practice competitive sport, which are also related to stereotypes, are addressed, among others, in the 2012 Social Project study (Włoch, 2013).

In the opinion of female players and student government activists, injuries were the most negative aspect of practicing football by women. Comparing the discipline with others, one can venture to say that no discipline is free from injuries. Their number does not depend solely on the vulnerability of women, but rather on the kind of training system (Niewolna, Zwierko, 2016), training conditions, physical rejuvenation forms (Chudecka, Lubkowska, 2010) and medical care. Injuries affect all athletes in many sports disciplines, regardless of gender. In epidemiological 
studies conducted between 1990 and 2003 among girls and boys who practiced football, it was observed that women suffered more injuries than men (in absolute figures). The most commonly injured parts of the body in girls were upper and lower limbs (wrist, finger, hand, ankle, knee). Girls were more likely to suffer from ankle joint injury than boys, who more often had head and neck injuries (Leininger, Knox, Cumstock, 2007).

The late 20th and early 21 st centuries have been the time of intensive change in sexual mores, connected with civilizational transformations, development of biological sciences, and increase of knowledge concerning human sexuality. This knowledge, along with civilizational changes, became the impulse for the sexual revolution, which is characterized by tolerance towards premarital sexual activity, cohabitation, diverse sexual orientations, and sex education (Marczak, 2011). In every culture, in every society there are certain stereotypes related to sexuality. They include athletes as well. For women engaged in football, being perceived as non-heterosexual is particularly painful. The reason for this unpleasant stereotype is practicing football, which is often regarded as a typically masculine discipline, as it was described above. The studied female footballers also had difficulty freeing themselves from this stereotype; they classified this discipline partly as typically masculine. This situation demonstrates the strength of the stereotype. The opinions of the players and CPEU activists testify to the existence of the malicious stereotype concerning non-heterosexuality among women who practice football. The issue of non-heterosexuality is most often mentioned in connection with 'masculine' sports. Attribution of this orientation to women (whether rightly or not) is a way to protect what is 'masculine' from what is 'feminine' (Jakubowska, 2014).

Z. Izdebski (2011) examining attitudes toward sexual minorities, found that the views of Polish people are not free from myths and stereotypes. Almost $2 / 3$ of the adult respondents (18-49 years old) said that sexual contacts between persons of the same sex are not normal. In the group of people over the age of 50 , in a study of tolerance toward non-heterosexuals it was found that almost half of the respondents expressed the opinion that they had nothing against non-heterosexual people if they do not demonstrate it (Izdebski, 2011). Homophobia is one of the most important problems faced by contemporary sport, but in Polish sport it is not mentioned (Jakubowska, 2014). The more valuable are the attitudes of female footballers, who were characterized by a high tolerance toward nonheterosexuality; it was higher among the players from the two highest leagues.

In some studies, it was emphasized that the majority of women who practiced football at the national level had an androgynous gender identity. It could be assumed that this personality type allows optimum adaptation to the conditions of functioning in football, but also in other sports disciplines (Soroka, Bergier, 2011) as well as in various areas of life.

In conclusion, it is worth noting that only some sports associations raise the issue of discrimination on grounds of gender in their statutes (Włoch, 2013). The clause in the Statute of the Polish Football Association on the prohibition of discrimination for the reason of gender with regard to practicing football, testifies to the recognition of this problem by sports authorities and activists.

\section{Conclusion}

1. The condition of practicing football by women is not only the issue of equal rights and freedom to choose discipline, but still- the need to combat negative stereotypes.

2. The 2nd League players most often indicated the following benefits of practicing football by women: opportunity to develop their personality, developing physical fitness and health and promoting the discipline among women. The Exstraliga players pointed to the frequent injuries accompanying the practicing of the sport. 
3. The opinions of the players (mostly of the Exstraliga players), as well as CPEU activists point to the functioning of the negative stereotype concerning the non-heterosexuality of women practicing football. Despite the functioning of the stereotype, the women from higher leagues were characterized by a higher level of tolerance toward non-heterosexuality.

4. There is an urgent need for public education to combat negative stereotypes concerning women practicing traditional masculine sports disciplines, as well as for tolerance toward people of a different sexual orientation.

\section{References}

Andreis, S. (2012). Piłkarzyce. Bez Dogmatu. Kwartalnik Kulturalno-Polityczny, 92-II.

Bergier, J. (2009). Wzorce charakterystyki gry działań ofensywnych zawodniczek piki nożnej. In: T. Socha, J. Bergier (eds.) Sport kobiet w Polsce - stan badań (pp. 75-85). Warszawa: MSiT, AWF.

Boguszewski, D., Adamczyk, J.G., Kerbaum, K., Antoniak, B., Obszyńska-Litwiniec, A., Białoszewski, D. (2015). Susceptibility to injury during falls in women practising combatsports and martial arts. Polish Journal of Sport and Tourism, 22 (1), 15-24.

Brzana, T., Nowak, L., Nowak, M.A. (2016). The fan lifestyle on the example of soccer fans. Central European Journal of Sport Sciences and Medicine, 15 (4), 81-94. DOI: 10.18276/cej.2016.3-09.

Butler, J. (2008). Uwikłani w płeć. Feminizm i polityka tożsamości. Translated by K. Krasuska. Warszawa: Wydawnictwo Krytyki Politycznej.

Chudecka, M. Lubkowska, A. (2010). Temperature changes of selected body's surfaces of handball players in the course of training estimated by thermovision, and the study of the impact of physiological and morphological factors on the skin temperature. Journal of Thermal Biology, 35 (8), 379-385.

Gieß-Stüber, P. (2000). Gleichberechtigte Partizipation im Sport? Ein Beitrag zur geschlechtsbezogenen Sportpädagogik. Köln: Czwalina Verlag.

Hively, K., El-Alayli, A. (2014). You Throw Like a Girl: The Effect of Stereotype Threat on Women's Athletic Performance and Gender Stereotypes. Psychology of Sport and Exercise, 15, 48-55. DOI: 10.1016/j.psychsport2013.09.001.

Izdebski, Z. (2011). Seksualność Polaków na początku XXI wieku. Studium badawcze. Kraków: Wydawnictwo Naukowe UJ.

Jakubowska, H. (2009). Socjologia ciała. Poznań: UAM. Seria Socjologia nr 59.

Jakubowska, H. (2012). Trzymanie kobiet na dystans. Wykorzystywanie kategorii płci, rasy i różnicy w profesjonalnym sporcie. Kultura i Społeczeństwo, 3, 75-94. DOI: 10.2478/v10276-012-0024-2.

Jakubowska, H. (2013). Płciowe porządki - granice płci w sporcie wg koncepcji Mary Douglas. Człowiek i Społeczeństwo, XXXVI (1), $113-127$.

Jakubowska, H. (2014). Od przemilczenia do coming outu - status mniejszości seksualnych w sporcie. Kultura i Społeczeństwo, 1, 155-167. DOI: 10.2478/kultura-2014-0019.

Jakubowska, H. (2015). Like a girl - media społecznościowe jako narzędzie kwestionowania porządku płci w sporcie. In: K. KopeckaPiech (ed.), Innowacyjność przemysłów kreatywnych. Media a sport (pp. 4-60). Wrocław: AWF.

Kofta, M., Jasińska-Kania, A. (ed.) (2001). Stereotypy i uprzedzenia. Uwarunkowania psychologiczne i kulturowe. Warszawa: Wydawnictwo Naukowe „Scholar”.

Konstytucja Rzeczypospolitej Polskiej z dnia 2 kwietnia 1997 r., Dz.U. z 16 lipca 2001 r., nr 78, poz. 483; sprost.: Dz.U. 2001, nr 28, poz. 319; art. 68, pkt 5, s. 34. Warszawa 2006.

Leininger, R.E., Knox, C.L., Cumstock, R.D. (2007). Epidemiology of 1.6 million pediatric soccer related injuries presenting to US emergency departments from 1990 to 2003. The American Journal of Sports Medicine, 35 (2), 288-293. DOI: $10.1177 / 0363546506294060$.

Mandal, E. (2000). Podmiotowe i interpersonalne konsekwencje stereotypów związanych z płcią. Katowice: Wydawnictwo Uniwersytetu Śląskiego.

Marczak, M. (2011). Przemiany postaw i zachowań seksualnych młodzieży. In: G. Iniewicz, M. Mijas (eds.), Seksualność człowieka. Wybrane zagadnienia (pp. 89-98). Kraków: Wydawnictwo Naukowe UJ.

Mazur, Z., Organista, N. (2015). Poziom agresywności kobiet uprawiających sporty rodzajowo męskie i kobiece. Journal of Education, Health and Sport, 5 (5),154-164. DOI: 10.5281/zenodo.17473. 
Mikołajczyk, M. (1995). Płeć psychologiczna kobiet uprawiających sport i nie uprawiających sportu. In: Z. Żukowska (ed.), Sport w życiu kobiety (pp. 45-55). Warszawa: PSSK, AWF.

Mikołajczyk, M. (2003). Czy sport musi mieć płeć? In: J. Kłodecka-Różalska J. (ed.), Sportsmenka - kobietą sukcesu... Korzyści i bariery aktywności sportowej kobiet (pp. 24-42). Warszawa: PSSK.

Niewolna, N., Zwierko, T. (2016). Program profilaktyki urazów w sporcie wysokokwalifikowanym. Handel Wewnętrzny, 6 (365), 300-308.

Nowak, M. (2008). Aktywność fizyczna w prozdrowotnym stylu życia kobiet. Poznań. AWF. Seria: Monografie 374.

Nowak, M., Kitowska, M., Rynkiewicz, T., Kuriańska-Wołoszyn, J., Żurek, P., Rynkiewicz, M. (2009). Health oriented attitudes in amateur sumo wrestlers. Archives of Budo, 5, 165-169.

Nowak, M., Kitowska, M., Rynkiewicz, T., Piekarski, R., Żurek, P., Rynkiewicz, M. (2010). Motives vs. age, training experience, and sporting level in sumo wrestlers. Archives of Budo, 6 (1), 7-12.

Organista, N. (2017). Underrepresentation of women in sports organizations. Polish, British and international organizations a comparative analysis. Central European Journal of Sport Sciences and Medicine, 3 [in press].

Osiński, W. (2002). Zarys teorii wychowania fizycznego. Poznań: AWF.

Pfister, G. (2003/2004). Female leaders in sports organisations - worldwide trends. Bulletin of International Association of Physical Education and Sport for Girls and Women, 12, 22-33.

Polki mistrzyniami Europy U-17-90 min.pl. Retrieved from: www.90minut.pl (20.04.2016).

Sahaj, T. (2012). Aktywność stadionowa kibicowskich grup „ultras” jako przejaw specyficznej komunikacji społecznej. Kultura i Społeczeństwo, 3, 27-49. DOI: 10.2478/v10276-012-0022-4.

Socha, T. (2002). Sport kobiet, historia, teoria, praktyka. Warszawa: COS.

Soroka, A., Bergier, J. (2011). Sense of gender identity in women practicing football with consideration of the formation, Sexual identity of female football players. Polish Journal of Sport and Tourism, 18, 45-58.

Statut PZPN Art. 7. Neutralność i niedyskryminacja. Retrieved from: www.pzpn.pl/public/635/47 (22.05.2017).

Szark-Eckardt, M. Napierała, M. Kuska, M. Żukowska, H. Żukow, W. (2013). Diversification of motor skills of girls and boys aged 14-16 years with secondary schools in Bydgoszcz. Journal of Health Sciences, 3 (5), 579-596.

Van Buuren, J., de Leeuw, J.V. (1992). Equality Constraints in Multiple Correspondence Analysis. Multivariate Behavioral Research, 27 (4), 567-583.

Włoch, R. (2013). Sport kobiet w Polsce: zaproszenie do diagnozy. Człowiek i Społeczeństwo, XXXVI (1), 20-25.

Włoch, R., Skóra, K., Szankin, K., Szeptycka, E. (2013). Bariery równouprawnienia w Polsce. Warszawa: MSiT.

Women's Football Across the National Associations 2014-2015. Raport UEFA. Retrieved from: www.uefa.com/MultimediaFiles/ Download/uefaorg/.../2203967 (12.01.2017).

Cite this anticle aS: Zdunek, B., Nowak, M.A. (2018). The Conditions of Practicing Association Football by Women. Central European Journal of Sport Sciences and Medicine, 2 (22), 39-50. DOI: 10.18276/cej.2018.2-05. 